NREL Response to the Report Study of the Effects on

Employment of Public Aid to Renewable Energy Sources from King Juan Carlos University (Spain)

Eric Lantz and Suzanne Tegen

White Paper NREL/TP-6A2-46261

August 2009

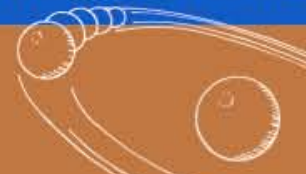




\section{NREL Response to the Report Study of the Effects on \\ Employment of Public Aid to Renewable Energy Sources from King Juan Carlos University (Spain)}

White Paper NREL/TP-6A2-46261

August 2009

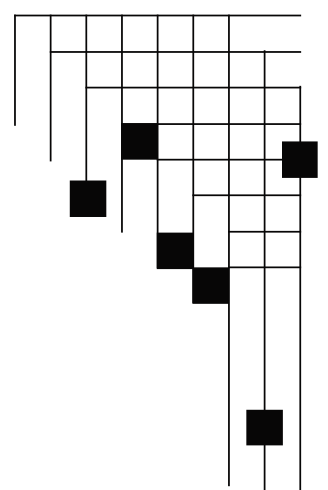

Prepared under Task No. SAO9.2011

National Renewable Energy Laboratory 1617 Cole Boulevard, Golden, Colorado 80401-3393 303-275-3000 • www.nrel.gov

NREL is a national laboratory of the U.S. Department of Energy

Office of Energy Efficiency and Renewable Energy

Operated by the Alliance for Sustainable Energy, LLC

Contract No. DE-AC36-08-GO28308 


\section{NOTICE}

This report was prepared as an account of work sponsored by an agency of the United States government. Neither the United States government nor any agency thereof, nor any of their employees, makes any warranty, express or implied, or assumes any legal liability or responsibility for the accuracy, completeness, or usefulness of any information, apparatus, product, or process disclosed, or represents that its use would not infringe privately owned rights. Reference herein to any specific commercial product, process, or service by trade name, trademark, manufacturer, or otherwise does not necessarily constitute or imply its endorsement, recommendation, or favoring by the United States government or any agency thereof. The views and opinions of authors expressed herein do not necessarily state or reflect those of the United States government or any agency thereof.

Available electronically at http://www.osti.gov/bridge

Available for a processing fee to U.S. Department of Energy and its contractors, in paper, from:

U.S. Department of Energy

Office of Scientific and Technical Information

P.O. Box 62

Oak Ridge, TN 37831-0062

phone: 865.576 .8401

fax: 865.576 .5728

email: mailto:reports@adonis.osti.gov

Available for sale to the public, in paper, from:

U.S. Department of Commerce

National Technical Information Service

5285 Port Royal Road

Springfield, VA 22161

phone: 800.553 .6847

fax: 703.605.6900

email: orders@ntis.fedworld.gov

online ordering: http://www.ntis.gov/ordering.htm 


\section{Background}

Job generation has been a part of the national dialogue surrounding energy policy and renewable energy (RE) for many years. RE advocates tout the ability of renewable energy to support new job opportunities in rural locations and the manufacturing sector. Others argue that spending on renewable energy is an inefficient allocation of resources and can result in job losses in the broader economy.

The report Study of the Effects on Employment of Public Aid to Renewable Energy Sources, from King Juan Carlos University in Spain, is one recent addition to this debate. The report asserts that, on average, every renewable energy job in Spain "destroyed" 2.2 jobs in the broader Spanish economy. The authors also apply this ratio in the U.S. context to estimate expected job loss from renewable energy development and policy in the United States (Alvarez et al. 2009).

The analysis by the authors from King Juan Carlos University represents a significant divergence from traditional methodologies used to estimate employment impacts from renewable energy. In fact, the methodology does not reflect an employment impact analysis. Accordingly, the primary conclusion made by the authors - policy support of renewable energy results in net jobs losses - is not supported by their work.

This white paper discusses fundamental and technical limitations of the analysis conducted by King Juan Carlos University and notes critical shortcomings in assumptions implicit in the conclusions. The white paper also includes a review of traditional employment impact analyses that rely on accepted, peerreviewed methodologies, and it highlights specific variables that can significantly influence the results of employment impact analysis.

\section{Summary of King Juan Carlos University Methodology}

The authors of the King Juan Carlos study intend to relate the economic efficiency of renewable energy jobs to those of the broader economy. To do this, they compare the government expenditure per estimated RE job with the average private-sector resources expended per worker and the average productivity per worker. Their quantitative approach is shown below.

Calculation A:

Calculation B:

$$
\frac{\text { Subsidy to renewables per worker }}{\text { Average capital per worker }}
$$

Annual subsidy to renewables per worker

The Spanish report asserts that the results derived from the ratios above represent job loss as a result of public investment in renewable energy. This is based on the assumed principle that every dollar spent subsidizing renewables represents a reduction of one dollar in private-sector investment and that every dollar spent in the private sector will generate jobs equally.

In contrast, traditional jobs analyses evaluate how changes in demand for specific goods and services will affect economic activity and jobs within specific industries, their supply chain, and the broader economy. The input-output tables applied in traditional analyses are derived from real inter-industry transactions at a specific time. The most sophisticated analyses account for a reduction in demand where 
substitutions occur (e.g., reduced demand for conventional electricity generation due to new renewable generation), as well as the effects of government expenditures and changes in commodity prices (e.g., electricity).

\section{Fundamental Limitations}

- The metrics used in the Spanish study are not jobs impact estimates. The primary conclusion of the report is that the Spanish economy has experienced job loss as a result of its RE installations. However, comparing the RE subsidy per job with the Spanish economy's average capital per job and average productivity per job is not a measure of job loss. Traditional methods for estimating jobs and economic impacts are discussed below.

- The comparison of $\mathrm{RE}$ jobs with average economy-wide metrics fails to recognize the variability within the modern economy. The cost of job creation varies significantly among economic sectors. For example, creating employment for legal or medical professionals costs more than creating employment for clerical or administrative professionals. Applying a methodology that compares renewable energy employment with an economy-wide average explains very little about how RE job creation compares with comparable industries. A more informative analysis would compare metrics relating to RE workers with metrics for workers in other electricity generating industries. It would also show the range of metrics that exist across industries rather than economywide averages. ${ }^{1}$

- The report fails to account for technology export potential. Robust RE technology exports can greatly affect economic impacts of renewable energy (Lehr et. al. 2008). With its proactive RE policies, Spain is already a major exporter of renewable energy equipment (David 2009). ${ }^{2}$ If global demand for RE technology increases, Spain's early investment could allow it to capitalize on a global market for RE technology, which would contribute further to the Spanish economy.

- The study ignores the role of government in facilitating growth of valued new industries. Governments invest in renewable energy technologies to promote the growth of the industry as a whole. Emerging RE technologies have not achieved levels of maturity and economies of scale that traditional technologies have; nor have they benefited from years of public and private investment. As a result, there may be a role for government to play in leveling the playing field between new and old technologies and in supporting emerging technologies. In the United States, all conventional energy technologies received government support in their early stages, and still benefit from government investment today (EIA 2008).

\section{Technical Limitations}

- The calculation of average capital and average productivity per worker is based on jobs resulting from economic activity at all levels (i.e., it includes direct, indirect, and induced jobs).

\footnotetext{
${ }^{1}$ These results could simply suggest that RE jobs require more highly trained - and, therefore, more costly - workers than the Spanish economy, in general. Moreover, the deviation from the economy-wide average capital and productivity per worker observed for renewables may be well within the statistical norms of a diverse and robust modern economy.

${ }^{2}$ Spain was the second-largest supplier of U.S. wind turbine generator imports in 2007 and 2008, and its overall exports of wind-powered generator sets reached $\$ 469.7$ million in 2008 (David 2009).
} 
However, the RE jobs estimate used to calculate the RE subsidy per job is based on a quantification of direct and indirect impacts only. The RE employment data used in this analysis is based on analysis of the direct and indirect job impacts from investment in renewable energy (MITRE 2003). Yet the average capital per worker and average productivity per worker are based on employment estimates that include jobs resulting from direct, indirect, and induced economic activity. A more complete comparison would include induced jobs impacts in the total RE jobs estimate that is used to estimate the average RE subsidy per worker. ${ }^{3}$

- The report relies on jobs estimates that were developed in 2003 and do not reflect Spain's RE industries in 2009. The total RE job creation estimate used by the authors was derived from two hypothetical Spanish deployment scenarios conducted in 2003 (MITRE 2003). However, neither of these projections reflects the actual deployment of renewable energy capacity in Spain. The authors imply that these results are a valid approximation. This approach ignores the discrepancies between assumptions that were reasonable in 2003 and the empirical reality that exists today.

- The report lacks transparency and supporting statistics. It is striking that the authors' calculations with two very different economic metrics generate the same result. The authors claim this increases their confidence in their result. However, because there is no statistical analysis, it does not seem reasonable to draw conclusions regarding confidence in either result. The authors also fail to justify their chosen methodology or cite others who have applied a similar methodology.

\section{Shortcomings in Assumptions}

- The authors assume that a dollar spent by the government is less efficient than a dollar spent by private industry and that it crowds out private investment. Government spending may be more or less efficient than private investment. To the extent that government spending is a correction for market failures (e.g., existing fossil fuel subsidies, environmental externalities), it is less likely to represent an inefficient allocation of resources. Furthermore, there is no justification given for the assumption that government spending (e.g., tax credits or subsidies) would force out private investment. This assumption is fundamental to the conclusion that Spain's renewable energy policy has resulted in job loss. ${ }^{4}$

Even if every public dollar spent on renewables does result in fewer jobs than the average dollar spent in the Spanish economy, public investment in renewables will only result in overall job loss when: there is full employment, all private-sector funds are spent on job-generating activity (i.e., not on shareholder dividends or paying down debt), and there is no positive benefit for the society from renewable energy in general. Without each of these conditions holding true, one cannot claim that public investment has resulted in job loss, regardless of the efficiency of the public investment.

- The authors assume that results from Spain are reflective of the impact of $\mathrm{RE}$ technologies in other countries. Countries have different regulations, policies, and incentives for renewable energy.

\footnotetext{
${ }^{3}$ Direct and indirect impacts include the impacts from expenditures in the industry of focus, as well as the various industries that supply the industry that is the subject of the analysis. Induced economic activity results from spending income generated through the original investments at the direct and indirect levels. A full social accounting matrix of economic activity includes all three levels of economic activity.

${ }^{4}$ Government spending may result in reallocation of resources.
} 
Minor policy differences can have great impacts on outcomes. Applying a single result derived from a specific set of market and policy conditions to renewable energy, in general, is a distortion of real differences in global market and policy conditions. For example, Spanish feed-in tariff (FIT) policies require utilities to purchase all electricity generated by RE resources at a price that is often much greater than the wholesale prices paid to conventional generators. This policy differs greatly from U.S. incentives such as the production tax credit (PTC).

- The report relies on jobs as the sole metric to assess the value of renewable energy. The number of jobs resulting from an impact analysis is an important metric. However, it is not the only value of interest. An analysis of relative costs per job within a specific industry or economy fails to account for the array of costs and benefits that are associated with any investment alternative. For example, Spain relies on natural gas and coal for roughly 52\% of its electricity production (IEA 2006). Decreasing that dependence has a number of important energy and economic security implications (NREL et. al. 2008).

In summary, the analysis performed in this recent study is not a jobs impact estimate and, therefore, provides little insight into job creation or job loss from Spanish RE policy. Additionally, this analysis has oversimplifications and assumptions that lead to questions regarding its quantitative results. Finally, the authors fail to justify their implication that because of the jobs comparison, subsidies for renewables are not worthwhile. This ignores an array of benefits besides employment creation that flow from government investment in renewable energy technologies.

Nevertheless, the authors' basic question regarding whether investment in RE provides a positive or negative employment impact is a fair one. The following portion of this white paper briefly reviews additional literature that considers this question.

\section{Traditional Employment Impacts Analysis}

Traditional methods applied in jobs and economic impacts analyses rely on input-output models to estimate job creation or loss. These models measure how changes in demand for specific goods and services affect economic activity and jobs within the specific area of study. At the most basic level, jobs analyses rely on a straightforward estimate of gross economic impacts from new investments in specific energy technologies under different scenarios. Such efforts in the United States suggest that, in some cases, the project-level job creation impacts of wind power are greater than that of conventional energy generation resources, including coal and natural gas (Tegen 2006, Lantz and Tegen 2008).

More sophisticated models allow for estimates of net jobs impacts. These models account for a reduction in demand for conventional generation, the effects of government expenditures on RE in the economy, and electricity price impacts. ${ }^{5}$ The results of analyses applying these more sophisticated models are mixed; however, with today's cost projections, RE technology jobs and impacts generally have been shown to be greater than business-as-usual scenarios. Some examples follow.

The Monitoring and Modeling Initiative on the Targets of Renewable Energy (MITRE) determined that across Europe, as well as in Spain, renewable energy development would have a net positive impact on

\footnotetext{
${ }^{5}$ Such models typically use a combination of input-output and macroeconomic modeling capabilities.
} 
employment (MITRE 2003). ${ }^{6}$ Work focused on Germany, conducted in 2005, found that feed-in tariff (FIT) policies in their country would result in a surge in employment between 2004 and 2008 as deployment proceeded rapidly; but net employment would turn negative in 2010 as construction of new facilities declined and the higher costs of renewable energy impacted the broader economy (Hillebrand et al. 2006). More recent work finds that, in Germany, net employment remains positive for all renewables deployment scenarios across a variety of sensitivities, and growing export markets greatly increase the net employment impact (Lehr et al. 2008). ${ }^{7}$ Finally, an April 2009 study conducted on behalf of the European Commission's Directorate-General Energy and Transport shows "[p]olicies that support renewable energy sources (RES) give a significant boost to the economy and the number of jobs in the EU. Improving current policies so that the target of $20 \%$ RES in final energy consumption in 2020 can be achieved will provide a net effect of about 410,000 additional jobs and $0.24 \%$ additional gross domestic product (GDP)" (Ragwitz et al. 2009).

In general, comprehensive analyses show that net employment impacts are sensitive to assumptions regarding future energy prices, strategies for addressing greenhouse gas (GHG) emissions reductions, and the capacity to export technology. With increased awareness of potential energy price scenarios, recent research has found that it is only when conventional energy prices are forecast to be very low that net employment impacts from RE investments are negative. ${ }^{8}$

\section{Conclusions}

The recent report from King Juan Carlos University deviates from the traditional research methodologies used to estimate jobs impacts. In addition, it lacks transparency and supporting statistics, and fails to compare RE technologies with comparable energy industry metrics. It also fails to account for important issues such as the role of government in emerging markets, the success of RE exports in Spain, and the fact that induced economic impacts can be attributed to RE deployment. Finally, differences in policy are significant enough that the results of analysis conducted in the Spanish context are not likely to be indicative of workforce impacts in the United States or other countries.

Energy policy has always been a politically charged subject. And in today's economy, where job creation is at a premium, questions pertaining to the impact of energy policy on employment magnify the sensitive nature of this debate. Measuring long-term economic and employment impacts is a complex task, sensitive to an array of unknowns, including future prices for both conventional fuel and renewable energy. Because this work is highly sensitive to assumptions and the quality of research, it is critical that policy makers seriously evaluate the work presented to them; and even after careful scrutiny, place jobs estimates within the broader context of energy, the economy, the environment, and the future.

\footnotetext{
${ }^{6}$ Remarkably, this is the same resource that the King Juan Carlos University authors use to argue that the Spanish economy is losing jobs as a result of its policies promoting renewable energy.

${ }^{7}$ Even with conservative assumptions relative to today's prices - where renewable energy is not expected to be wholly costcompetitive until 2020 (at oil prices of $\$ 60$ per barrel in 2020 and $\mathrm{CO}_{2}$ at $€ 15$ per ton) - there is a net positive impact that is further boosted by technology exports. It is only in the most extreme scenarios with very low energy prices (\$30 per barrel oil in 2020) and no exports of RE equipment, that the net employment impact of Germany's feed-in tariff policies is negative (Lehr et al. 2008).

${ }^{8}$ In most recent analysis, electricity-price increases from renewable energy deployment are minimal. The U.S. Energy Information Administration's analysis of two scenarios with a national 25\% renewable energy standard (RES) showed that national electricity prices are impacted by less than 1\% by 2030 (EIA 2009). A similar NREL report showed that of the RES proposals analyzed, no state experiences electricity price increases of more than 5\%, and most states actually experience electricity price decreases rather than increases (Sullivan et al. 2009).
} 


\section{References}

Alvarez, G.C.; Merion Jara, R.; Rallo Julian, J.R. (2009). Study of the Effects on Employment of Public Aid to Renewable Energy Sources. King Juan Carlos University. March 2009.

David, A.S. (2009). Wind Turbines Industry \& Trade Summary. Published for the U.S. International Trade Commission. June 2009.

http://www.usitc.gov/ind econ_ana/research ana/ind trade_summ/documents/ITS-2 Summary.pdf

Energy Information Administration (U.S.) (EIA). (2009). Impacts of a 25-Percent Renewable Electricity Standard as Proposed in the American Clean Energy and Security Act Discussion Draft. April 2009. SR-OIAF/2009-04.

EIA. (2008). Federal Financial Interventions and Subsidies in Energy Markets. April 2008. $\mathrm{SR} / \mathrm{CNEAF} / 2008-01$.

Hillebrand, B.; Buttermann, H.G.; Behringer, J.M.; Bleuel, M. (2006). "The Expansion of Renewable Energies and Employment Effects in Germany. ”Energy Policy 34 (2006) 3484-3494.

International Energy Agency (IEA). (2006). Energy Statistic by Country: Spain 2006. http://www.iea.org/textbase/stats/countryresults.asp?COUNTRY CODE=ES

Lantz, E.; Tegen, S. (2008). Variables Affecting Economic Development from Wind Energy. July 2008. NREL/CP-500-43506.

Lehr, U.; Nitsch, J.; Kratzat, M.; Lutz, C.; Dietmar, E. (2008). "Renewable Energy and Employment in Germany." Energy Policy 36 (2008) 108-117.

Monitoring and Modeling Initiative on the Targets for Renewable Energy (MITRE) (2003). Meeting the Targets and Putting Renewables to Work: Country Report Spain. Produced for the European Commission, 2003.

National Renewable Energy Laboratory (NREL), and World Resources Institute, in cooperation with the Center for Strategic and International Studies. (2008). "Opportunities for High Impact U.S. Government International Renewable Energy and Energy Efficiency Initiatives.”

Ragwitz, M.; Schade, W.; Breitschpf, B.; Walz, R.; Helfrich, N.; Rathman, M.; Resch, G; Faber, T.; Panzer, C.; Haas, R.; Nathani, C.; Holzhey, M.; Zagame, P.; Fougeyrollas, A.; Konstantinaviciute, I. (2009). Published for the European Commission DG Energy and Transport. The impact of renewable energy policy on economic growth and employment in the European Union. April 2009.

Sullivan, P.; Logan, J.; Bird, L.; Short, W. (2009). Comparative Analysis of Three Proposed Federal Renewable Electricity Standards. May 2009. NREL/TP-6A2-45877.

Tegen, S. (2006). Comparing Statewide Economic Impacts of New Generation from Wind, Coal, and Natural Gas in Arizona, Colorado, and Michigan. May 2006. NREL/TP-500-37720. 


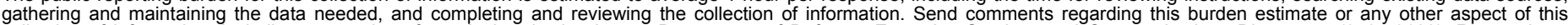

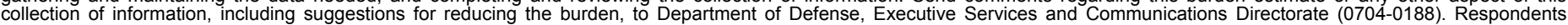

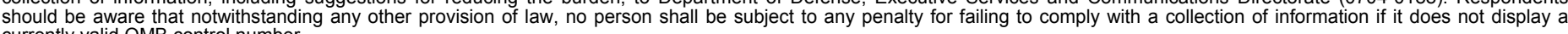

PLEASE DO NOT RETURN YOUR FORM TO THE ABOVE ORGANIZATION.
1. REPORT DATE (DD-MM-YYYY) August 2009
4. TITLE AND SUBTITLE
NREL Response to the Report Study of the Effects on Employment of Public Aid to Renewable Energy Sources from King Juan Carlos University (Spain)
2. REPORT TYPE
White Paper

6. AUTHOR(S)

E. Lantz and S. Tegen
3. DATES COVERED (From - To)

5a. CONTRACT NUMBER

DE-AC36-08-GO28308

5b. GRANT NUMBER

5c. PROGRAM ELEMENT NUMBER

5d. PROJECT NUMBER

NREL/TP-6A2-46261

5e. TASK NUMBER

SAO9.2011

5f. WORK UNIT NUMBER

7. PERFORMING ORGANIZATION NAME(S) AND ADDRESS(ES)

National Renewable Energy Laboratory

1617 Cole Blvd.

Golden, CO 80401-3393

9. SPONSORING/MONITORING AGENCY NAME(S) AND ADDRESS(ES)

10. SPONSOR/MONITOR'S ACRONYM(S) NREL

11. SPONSORING/MONITORING AGENCY REPORT NUMBER

\section{DISTRIBUTION AVAILABILITY STATEMENT}

National Technical Information Service

U.S. Department of Commerce

5285 Port Royal Road

Springfield, VA 22161

13. SUPPLEMENTARY NOTES

\section{ABSTRACT (Maximum 200 Words)}

Job generation has been a part of the national dialogue surrounding energy policy and renewable energy (RE) for many years. RE advocates tout the ability of renewable energy to support new job opportunities in rural locations and the manufacturing sector. Others argue that spending on renewable energy is an inefficient allocation of resources and can result in job losses in the broader economy. The report Study of the Effects on Employment of Public Aid to Renewable Energy Sources, from King Juan Carlos University in Spain, is one recent addition to this debate. The report asserts that, on average, every renewable energy job in Spain "destroyed" 2.2 jobs in the broader Spanish economy. The authors also apply this ratio in the U.S. context to estimate expected job loss from renewable energy development and policy in the United States. This white paper discusses fundamental and technical limitations of the analysis conducted by King Juan Carlos University and notes critical shortcomings in assumptions implicit in the conclusions. The white paper also includes a review of traditional employment impact analyses that rely on accepted, peer-reviewed methodologies, and it highlights specific variables that can significantly influence the results of employment impact analysis.

15. SUBJECT TERMS

NREL; renewable energy; job generation; RE; King Juan Carlos University of Spain; U.S. jobs; employment; analysis; job impacts; job development; energy sources; manufacturing; Eric Lantz; Suzanne Tegen

\begin{tabular}{|c|c|c|c|c|}
\hline 16. SECURITY & CLASSIFICATI & N OF: & 17. LIMITATION & 18. NUMBER \\
\hline $\begin{array}{l}\text { a. REPORT } \\
\text { Unclassified }\end{array}$ & $\begin{array}{l}\text { b. ABSTRACT } \\
\text { Unclassified }\end{array}$ & $\begin{array}{l}\text { c. THIS PAGE } \\
\text { Unclassified }\end{array}$ & $\begin{array}{l}\text { OF ABSTRACT } \\
\text { UL }\end{array}$ & \\
\hline
\end{tabular}

